\title{
SULUH
}

JURNAL BIMBINGAN DAN KONSELING

http: //journal.umpalangkaraya.ac.id/index.php/suluh

\section{IDENTIFIKASI CIRI-CIRI PENYEBAB PERILAKU AGRESIF VERBAL DAN PERILAKU AGRESIF NON VERBAL PADA SMP NEGERI 13 PALANGIKA RAYA}

\section{Identification Of The Characteristics Of Verbal Agressive Behavior And Verbal Agressive Behavior In Palangka Raya 13 State SIMP}

'M. Andri Syarifullah, ${ }^{2}$ Dina Fariza TS

IUniversitas Muhammadiyah Palangkaraya, Jekan Raya, Palangka Raya, Kalimantan Tengah, Indonesia

2 Universitas Muhammadiyah Palangkaraya, Jekan Raya, Palangka Raya, Kalimantan Tengah, Indonesia

\begin{abstract}
ARTIKEL INFO
ABSTRAK

Diterima

Desember 2017

Penelitian ini bertujuan untuk mengidentifikasi ciri-ciri penyebab perilaku agresif verbal dan perilaku agresif non verbal. Jenis penelitian yang digunakan adalah pendekatan deskriptif kuantitatif. Dengan jumlah sampel 83 peserta didik. Data analisis dengan rumus presentase menggunakan apliaksi software SPSS versi 20 Hasil penelitian menunjukan bahwa: (1) faktor penyebab perilaku agresif verbal peserta didik pada SMP Negeri 13 Palangka Raya di kategorikan sangat dominan (84\%) pada indikator membantah. (2) faktor penyebab perilaku agresif non verbal (fisik) peserta didik pada SMP Negeri 13 palangka Raya di kategorikan sangat dominan yaitu terdapat dua indikator: indikator suka mencuri $(90 \%)$, dan indikator

Dipublikasi suka merusak barang milik orang lain (86\%)
\end{abstract}

Februari 2018

Kata kunci: agresif verbal dan agresifnon verbal

*E-mail:

dinafarizaTS@gmail.com

\section{ABSTRACT}

This study aims to identify the characteristics of aggressive verbal behavior and non verbal aggressive behavior. The type of research used is a quantitative descriptive approach. With a sample of 83 students. Data analysis using the percentage formula using SPSS software version 20. The results of the study show that: (I) the factors causing verbal aggressive behavior of students in Palangka Raya Public Middle 13 are categorized as very dominant (84\%) in the indicator denies. (2) the causes of non verbal (physical) aggressive behavior of students in Palangka Raya 13 Junior High School are categorized as very dominant, namely there are two indicators: indicators like to steal (90\%), and indicators like to damage other people's property (86\%)

Keywords: aggressive verbal and aggressive non verbal

Orchid: 


\section{PENDAHULUAN}

Masa remaja seringkali dikenal dengan masa mencari jati diri, ini terjadi karena masa remaja merupakan masa peralihan antara masa kehidupan anak-anak dan masa kehidupan orang dewasa. Dilihat dari segi fisiknya, remaja sudah bukan anak-anak lagi melainkan sudah seperti orang dewasa, tetapi jika remaja diperlakukan seperti orang dewasa, ternyata belum dapat menunjukkan sikap dewasa. Menurut Ali dan Asrori (2010: 9) remaja dalam bahasa aslinya adolescence, berasal dari bahasa Latin adolescere yang artinya "tumbuh atau tumbuh untuk mencapai kematangan”. Perkembangan lebih lanjut, remaja menurut Fitriyah dan Jauhar (2014: 76) suatu periode transisi dari masa awal anakanak hingga masa awal dewasa, masa remaja bermula pada perubahan fisik yang cepat, pertambahan berat badan, dan perubahan bentuk tubuh. Pandangan ini juga didukung oleh Piaget (dalam Ali dan Asrori, 2010: 9) yang mengatakan bahwa secara psikologis, remaja adalah "suatu usia dimana individu menjadi terintegrasi ke dalam masyarakat dewasa, suatu usia dimana anak tidak merasa bahwa dirinya berada di bawah tingkat orang yang lebih tua melainkan merasa sama, atau paling tidak sejajar". Masa sekolah menengah pertama adalah masa remaja awal dengan rentang usia I2-15 tahun. Dalam perkembangan remaja awal untuk anak sekolah menengah pertama ini tentunya juga mempunyai ciri-ciri masa remaja tertentu, menurut Jahja (20II: 236) salah satu ciri-ciri masa remaja yaitu kebanyakan remaja bersikap ambivalen dalam menghadapi perubahan yang terjadi, disuatu sisi mereka menginginkan kebebasaan tetapi disisilain mereka takut akan tanggung jawab yang menyertai kebebasaan ini serta meragukan kemampuan mereka sendiri untuk memikul tanggung jawab.

Selanjutnya Biehler (dalam Fatimah, 2006: 108) mengemukakan bahwa ciri-ciri perkembangan emosional remaja awal yang berusia 12-15 tahun diantaranya: (a) Cenderung bersikap pemurung, (b) Ada kalanya berperilaku kasar untuk menutupi kekurangan dalam hal rasa percaya diri, (c) Ledakan-ledakan kemarahan sering terjadi sebagai akibat dari kombinasi ketegangan psikologis, ketidakstabilan biologis, dan kelelahan karena bekerja terlalu keras atau pola makan yang tidak tepat atau tidur yang tidak cukup, (d) Cenderung berperilaku tidak toleran terhadap orang lain dengan membenarkan pendapatnya sendiri, dan (e) Mengamati orangtua dan guru-guru secara lebih objektif dan mungkin marah apabila tertipu dengan gaya guru yang bersikap serba tahu (mahatahu).

Ciri-ciri perkembangan emosi remaja awal tersebut akan membawa pengaruh kepada perilaku peserta didik selaku remaja awal. Hal ini dimulai dengan perilaku peserta didik disekolah yang akan menunjukkan perubahan hubungan antara siswa dan guru. Kadang-kadang peserta didik akan menceritakan kepada guru informasi pribadi yang tidak mau mereka ceritakan kepada orang tua mereka. Beberapa peserta didik bahkan memilih guru sebagai panutan. Namun, pada saat yang sama, beberapa peserta didik membantah guru dengan cara yang belum pernah mereka pikirkan beberapa tahun sebelumnya, dan beberapa menantang guru secara terbuka, hal ini dapat terjadi karena masa remaja awal biasanya masih memiliki energi yang besar, emosi yang masih belum stabil, sedangkan pengendalian diri belum sempurna. Remaja sebetulnya tidak mempunyai tempat yang jelas. Mereka sudah tidak termasuk golongan anak-anak, tetapi belum juga dapat diterima secara penuh untuk masuk kegolongan orang dewasa. Remaja ada diantara anak dan orang dewasa. Oleh karena itu, remaja sering kali dikenal dengan "fase mencari jati diri" atau fase "topan dan badai", dimana remaja masih belum mampu 
menguasai dan memfungsikan secara maksimal fungsi fisik maupun psikisnya. Namun, yang perlu ditekankan disini adalah bahwa fase remaja merupakan fase perkembangan yang tengah berada pada masa amat potensial, baik dilihat dari aspek kognitif, emosi maupun fisik. Masa seperti ini biasanya dirasakan sebagai masa sulit, baik bagi remaja sendiri maupun bagi keluarga, atau lingkungan.

Masa remaja dapat menjadi beresiko besar bagi banyak orang karena anak-anak berusia belasan tahun dapat untuk pertama kalinya terlibat ke dalam perilaku atau mengambil keputusan yang mempunyai konsekuensi negatif jangka panjang. Tidak tercapainya keinginan menimbulkan perasaan yang tidak nyaman kemudian terwujud menjadi frustasi yang akan menimbulkan kemarahan sehingga memicu untuk berperilaku agresif. Menurut Berkowitz (2006: 4) perilaku agresif adalah "segala bentuk perilaku yang dimaksudkan untuk menyakiti seseorang baik secara fisik maupun mental". Perilaku agresif pada peserta didik merupakan bagian dari kenakalan remaja yang harus dikendalikan bersama orang tua, guru, remaja sendiri, dan masyarakat.Tidak tercapainya keinginan peserta didik sebagai remaja maka akan mudah sekali untuk melakukan tindakan yang dapat menyakiti orang lain baik itu fisik maupun mental. Kalau berbicara tentang perilaku, maka perilaku dapat verbal dan non-verbal (fisik). Menyakiti perasaan atau mental orang lain dapat dikatakan sebagai perilaku agresif verbal sedangkan menyakiti fisik orang lain yang dilakukan siswa dapat dikatakan sebagai perilaku agresif. Perilaku agresif yang dilakukan oleh peserta didik disekolah sering kali tidak dapat dihindari meski dengan pengajaran yang baik sekalipun karena hal ini juga dapat disebabkan oleh faktor dari luar sekolah.

Berdasarkan hasil observasi di SMP Negeri I3 Palangkaraya terlihat bahwa terdapat peserta didik yang melakukan tindakan perilaku agresif verbal dan non verbal (fisik) terhadap temannya seperti mengejek temannya dengan ejekan nama orang tua, menghina keadaaan fisik temannya, memaki dengan kata-kata kotor, menyalahkan temannya padahal dia yang bersalah, berkatakata kasar apabila dirinya emosi kepada temannya meskipun temannya tidak bersalah pada dirinya, menertawakan temannya sehingga temannya merasa malu, marahmarah tanpa alasan kepada temannya. Sedangkan pada saat wawancara yang dilakukan kepada guru mata pelajaraan dan guru bimbingan dan konseling di SMP Negeri I3 Palangka Raya pada bulan oktober 2016, terdapat peserta didik yang namanya tercatat di dalam buku catatan peserta didik di ruang guru bimbingan konseling dengan permasalahan berkelahi contohnya: peserta didik yang sering mengejek dan menghina teman dan peserta didik yang melakukan tindakan yang menyerang secara fisik, melakukan pelanggran aturan, merusak barang-barang milik teman. Salah satu peserta didik ini dalam kurung waktu sebulan tercatat empat kali melakukan perkelahian dengan peserta didik lainnya.

Dari masalahan yang terjadi peneliti tertarik mengambil judul yaitu " Identifikasi Ciri-ciri Penyebab Perilaku Agresif verbal dan Perilaku Agresif Non Verbal pada SMP Negeri I 3 Palangka Raya

\section{METODOLOGI PENELITIAN}

Metode merupakan hal yang sangat penting dalam penelitian sebab tanpa adanya metode penelitian yang dilakukan tidak dapat dipertanggung jawabankan secara ilmiah. Berdasarkan permasalahan yang akan diteliti maka di dalam penelitian ini pneliti menggunakan metode deskriptif kuantitatif. $\mathrm{Hal}$ ini seperti apa yang di kemukakan oleh Arikunto, (2008: 190) yang menyatakan bahwa "penelitian deskriptif merupakan 
penelitian yang dimaksud untuk mengumpulkan informasi mengenai status suatu gejala yang ada yaitu keadaan segala menurut apa adanya pada saat penelitian dilakukan".

Metode deskriptif ini mempunyai sifatsifat atau ciri-ciri tertentu seperti memusatkan diri pada masalah yang aktual dan data-data yang dikumpulkan mula-mula disusun dan dijelaskan kemudian dianalisa. Penelitian deskriptif pada umumnya data yang dikumpulkan melalui angket dan obeservasi sebagai pelangkap dalam pengumpulan data di penelitian ini.

\section{HASIL DAN PEMBAHASAN}

I. Ciri-ciri Penyebab Perilaku Agresif verbal Berdasarkan hasil penelitian di SMP Negeri I 3 Palangka Raya yang telah dilakukan peneliti dengan pengumpulan data secara angket masih banyak memiliki ciri-ciri perilaku agresif verbal. Adapun hasil dari angket tersebut yang telah disebarkan oleh responden adalah sebagai berikut.

Tabel I

Perilaku Membantah Tidak Mau Apabila Disuruh Oleh Guru

\begin{tabular}{lccc}
\hline $\begin{array}{c}\text { Tentang } \\
\text { Pertanyaan }\end{array}$ & $\begin{array}{c}\text { Alternatif Jawaban } \\
\text { Respond Jumlah } \\
\text { en }\end{array}$ & $\begin{array}{c}\text { Persentase } \\
\text { (\%) }\end{array}$ \\
\hline Kalau guru suka & SR & 70 & $84 \%$ \\
menyuruh maka & KD & 10 & $12 \%$ \\
saya akan & JR & 1 & $1 \%$ \\
membantah & TP & 2 & $2 \%$ \\
tidak mau. \\
guru menyuruhnya dengan jawaban Sering \\
84\% dengan kategori sangat dominan, \\
Kadang-kadang I2\% kategori sangat kurang \\
dominan, Jarang I\% kategori sangat kurang \\
dominan, dan Tidak pernah 2 \% dengan \\
kategori sangat kurang dominan. \\
Dari uraian diatas, disimpulkan bahwa \\
perilaku membantah tidak mau ketika di \\
suruh oleh gurunya dikategorikan sangat \\
dominan yaitu 84\%. \\
2. Ciri-ciri Penyebab Perilaku Agresif Non \\
Verbal (fisik)
\end{tabular}

Berdasarkan hasil penelitian di SMP Negeri I 3 Palangka Raya yang telah dilakukan dengan cara mengumpulkan data angket, maka hasil dari angket tersebut yang telah disebarkan responden adalah sebagai berikut

Tabel 2

Perilaku Mencuri Apabila Tidak Dapat Uang jajan

\begin{tabular}{lccc}
\hline $\begin{array}{c}\text { Tentang } \\
\text { Pertanyaan }\end{array}$ & \multicolumn{3}{c}{ Alternatif Jawaban } \\
& Responden & Jumlah & $\begin{array}{c}\text { Persenta } \\
\text { se (\%) }\end{array}$ \\
\hline Saya akan & SR & 75 & $90 \%$ \\
mencuri & KD & 2 & $2 \%$ \\
apabila saya & JR & 4 & $4 \%$ \\
tidak dapat & TP & 2 & $2 \%$ \\
uang jajan & & & \\
\hline
\end{tabular}

Dari tabel di atas siswa yang mencuri apabila tidak dapat uang jajan dengan jawaban Sering $90 \%$ dengan ketegori sangat dominan, Kadang-kadang $2 \%$ dengan kategori sangat kurang dominan, Jarang $4 \%$ dengan kategori sangat kurang dominan dan Tidak pernah 2\% dengan kategori sangat kurang dominan.

Dari uraian diatas, disimpulkan bahwa perilaku agresif yang suka mencuri apabila tidak dapat uang jajan dikategorikan sangat dominan yaitu $90 \%$

Tabel 3

Perilaku Suka Memberikan Permen Karet Diatas Kursi Teman

\begin{tabular}{lcll}
\hline $\begin{array}{c}\text { Tentang } \\
\text { Pertanyaan }\end{array}$ & \multicolumn{3}{c}{ Alternatif Jawaban } \\
& Responden & Jumlah & $\begin{array}{c}\text { Persentase } \\
\text { (\%) }\end{array}$ \\
\hline Saya suka & SR & 72 & $86 \%$ \\
memberikan & KD & 8 & $9 \%$ \\
perman & JR & I & $1 \%$ \\
karet di atas & TP & 2 & $2 \%$
\end{tabular}

kursi teman

saya

Dari tabel di atas siswa yang suka memberiakan permen karet di atas kursi temannya dengan jawaban Sering $86 \%$ dengan kategori sangat dominan, Kadang-kadang 8\% dengan kategori sangat kurang dominan, Jarang $1 \%$ dengan kategori sangat kurang dominan, dan Tidak pernah $2 \%$ dengan kategori sangat kurang dominan. 
Jurnal Bimbingan dan Konseling

Dari uraian diatas, disimpulkan bahwa perilaku agresif yang suka memberikan permen karet di atas kursi temannya dikategorikan sangat dominan yaitu $86 \%$.

\section{KESIMPULAN}

Berdasarkan hasil temuan peneliti maka dapat disimpulkan ciri-ciri teridentifikasi yaitu sebagai berikut:

I. Bentuk Perilaku Agresif Verbal

Ciri-ciri perilaku agrsif verbal pada peserta didik di SMP Negeri I 3 Palangka Raya yaitu mengejek teman, membantah, menghina, bertengkar mulut, menakut-nakuti, memanggil dengan nada kasar atau berbicara kasar, menyalahkan dan menertawakan, membantah ketika di tegur, berbohong, dan berbicara kasar. Ciri-ciri penyebab perilaku agresif verbal peserta didik pada SMP Negeri 13 Palangka Raya di kategorikan sangat dominan (84\%) pada indikator membantah.

2. Bentuk Perilaku Agresif Non Verbal (fisik)

Ciri-ciri perilaku agresif non-verbal (fisik) pada SMP Negeri 13 Palangka Raya seperti menyontek, suka mencuri, suka merusak barang milik teman, melakukan kekejaman terhadap teman, suka mengganggu teman, tidak disiplin, suka bertengkar, dan melakukan pelanggaran peraturan. Ciri-ciri penyeban perilaku agresif verbal (fisik) peserta didik pada SMP Negeri I3 Palangka Raya di kategorikan sangat dominan yaitu terdapat dua indikator: (I) indikator suka mencuri (90\%), dan (2) indikator suka merusak barang milik orang lain (86\%).

\section{DAFTAR PUSTAKA}

Ali Mohammad \& Asrori Mohammad. 2010. Psikologi Remaja. Jakarta: PT. Bumi Aksara.

Berkowitz, Leonard.2006. Emotional Behavior. (Terjemahan Hartatni W.S).Jakarta: CV. Trauna Gravica.

Fitriyah \& Jauhar. 20I4. Pengantar Psikologi Umum.Jakarta: Prestasi Pustakaraya
Fatimah, Enung. 2006. Psikologi Perkembangan. Bandung: CV. Pustaka Setia

Jahja,Yudrik 20II. Psikologi Perkembangan. Jakarta: PT. Karisma Putra Utama

Suharsimi Arikunto.2008. Manajemen Penelitian. Jakarta: Rineka Cipta. 